\title{
IMPACT OF MULTIFUNCTIONAL BIODIESEL FUEL ADDITIVE ON DIESEL ENGINE COMBUSTION PROCESS
}

\author{
Risto Ilves, Arne Kuut, Keio Kuut, Juri Olt \\ Estonian University of Life Sciences, Estonia \\ risto.ilves@emu.ee
}

\begin{abstract}
The use of fuel additives in engine fuels is a widespread tendency, and one which occurs on a worldwide basis. The most common area in the development of additives is for petrol and diesel fuel. The manufacturers claim that additives emulsify condensation water in the fuel tank, cleaning the fuel supply system and decreasing fuel consumption by improving the engine combustion process. Several additives have been developed for biofuels such as, for example, Valvoline VPS HD Diesel System Complete, which has been developed for biodiesel fuel. The manufacturers state that additives clean the fuel supply system and restore the engine power, which is something that could be reduced in cases in which biodiesel fuel is used. Moreover, soot emissions in exhaust fumes are decreased. According to the aforementioned points, fuel additives should have a significant impact on the engine combustion process in order to ensure improvements in the parameters that have been mentioned. In order to see the true picture, this article analyses the impact of biodiesel fuel with an additive, along with undiluted biodiesel fuel and diesel fuel, on the engine combustion process. More specifically, variations in the combustion pressure and combustion phases are being analysed. What is more, the heat release rate, heat release and cylinder working values are calculated, and the engine efficiency, fuel consumption, and exhaust emission levels are presented. The results indicate that this specific fuel additive does not have a significant impact on the engine combustion process.
\end{abstract}

Keywords: diesel fuel, RME, compression ignition engine, heat release rate, heat release, exhaust emissions, exhaust fumes.

\section{Introduction}

The impact of fuel additives on internal combustion engines has been discussed in several studies [1-10]. The results show that there are several additives, which have an impact on the engine performance parameters and emission levels. The additives discussed in these studies are specific and have an impact on a certain parameter of the fuel such as, for example, the cetane number or oxygen content $[5 ; 7]$. The universal additives for which improved fuel properties have not been specified usually do not have an impact on the engine performance parameters [2]. Therefore, the effectiveness of using fuel additives remains disputable, and their impact on the engine should be studied. Fuel additives have been developed for biofuels such as, for example, biodiesel fuel; however, the effect of these additives on the engine performance parameters and exhaust emission levels remains lower than when compared to the use of diesel fuel [11]. This is caused by the different physico-chemical properties of biofuel in comparison to diesel fuel. The universal fuel additives for biofuels usually do not improve the engine performance parameters. There may, however, be a slight improvement in the engine exhaust emissions [1].

Scientific studies that have been carried out on the impact of fuel additives often do not analyse the combustion process, which makes it difficult to properly assess the effect of fuel additives on fuel combustion. For example, the article by Baranauskas et al, 2015 [1], does not analyse the combustion process, which involves the universal fuel additive, Valvoline VPS HD Diesel System Complete, which may reveal a certain level of impact by the fuel additive on the combustion efficiency of the air-fuel mixture. Therefore, this study addresses the impact of the fuel additive, Valvoline VPS HD Diesel System Complete, on the combustion process in order to improve the data and analysis, which has been presented in the article by Baranauskas et al, 2015 [1].

The purpose of this article is to analyse the impact of the fuel additive, Valvoline VPS HD Diesel System Complete, on the diesel engine combustion process when biodiesel fuel is used (RME). The analysis is able to highlight the heat release rate (HRR), and data covering heat release (HR) and cylinder work. In addition, the change of combustion phases is studied when using diesel fuel, biodiesel fuel, and biodiesel fuel with fuel additives. It is important to compare data against diesel fuel data in order to understand which changes in the combustion process have been caused by fuel properties and which are the result of fuel additives. 


\section{Materials and methods}

The fuel additive, Valvoline VPS HD Diesel System Complete, is mixed with biodiesel fuel at a recommended ratio of $1 / 1000$. In order to improve a diesel engine starting properties or reduce the levels of soot that are emitted from it, the additive may be used at a higher ratio. The fuel additive has been described in detail in the article by Baranauskas et al, 2015 [1].

In order to study the impact of the Valvoline VPS HD Diesel System Complete fuel additive on the combustion process of a diesel engine, the biodiesel fuel (RME) and the additive were mixed at a ratio of 1/100. The test fuels being used for this engine test included diesel fuel as well as RME. The physico-chemical properties of the diesel fuel and the RME have been presented in Table 1.All of the properties have been measured in a certified lab to ascertain that fuels meet the standards.

Table 1

Properties of test fuels according to the EN 14214 and EN 590 standards [1]

\begin{tabular}{|c|c|c|c|c|c|}
\hline \multicolumn{3}{|c|}{ RME } & \multicolumn{3}{|c|}{ Diesel fuel } \\
\hline Characteristic & $\begin{array}{c}\begin{array}{c}\text { Unit of } \\
\text { measurement }\end{array} \\
\end{array}$ & $\begin{array}{l}\text { Actual } \\
\text { results }\end{array}$ & Characteristics & $\begin{array}{c}\begin{array}{c}\text { Unit of } \\
\text { measurement }\end{array} \\
\end{array}$ & $\begin{array}{l}\text { Actual } \\
\text { results }\end{array}$ \\
\hline Density at $15^{\circ} \mathrm{C}$ & $\mathrm{kg} \cdot \mathrm{m}^{-3}$ & 884.7 & $\begin{array}{c}\text { Density at } \\
15^{\circ} \mathrm{C}\end{array}$ & $\mathrm{kg} \cdot \mathrm{m}^{-3}$ & 829.1 \\
\hline Cetanenumber & - & 53.4 & Cetanenumber & - & 54 \\
\hline $\begin{array}{c}\text { Kinematic } \\
\text { viscosity at } 40^{\circ} \mathrm{C}\end{array}$ & $\mathrm{mm}^{2} \cdot \mathrm{s}^{-1}$ & 4.789 & $\begin{array}{c}\text { Kinematic } \\
\text { viscosityat } 40^{\circ} \mathrm{C}\end{array}$ & $\mathrm{mm}^{2} \cdot \mathrm{s}^{-1}$ & 2.067 \\
\hline Flash point & ${ }^{\circ} \mathrm{C}$ & 178 & Flash point & ${ }^{\circ} \mathrm{C}$ & 60.5 \\
\hline $\begin{array}{l}\text { Carbon residue } \\
\text { (on a } 10 \% \\
\text { distillation } \\
\text { residue) } \\
\end{array}$ & $\%$ & 0.29 & $\begin{array}{l}\text { Carbon residue } \\
\text { (on a } 10 \% \\
\text { distillation } \\
\text { residue) } \\
\end{array}$ & $\%$ & 0.022 \\
\hline Oxidation stability & $g \cdot m^{-3}$ & 6.4 & $\begin{array}{c}\text { Oxidation } \\
\text { stabilityat } 110^{\circ} \mathrm{C} \\
\end{array}$ & $\mathrm{g} \cdot \mathrm{m}^{-3}$ & 4 \\
\hline $\begin{array}{c}\text { Copper } \\
\text { stripcorrosion }(3 \\
\left.\text { hours at } 50^{\circ} \mathrm{C}\right)\end{array}$ & rating & Class 1 & $\begin{array}{c}\text { Copper } \\
\text { stripcorrosion }(3 \\
\left.\text { hours at } 50^{\circ} \mathrm{C}\right)\end{array}$ & rating & Class 1a \\
\hline Water content & $\mathrm{mg} \cdot \mathrm{kg}^{-1}$ & 250 & Water content & $\mathrm{mg} \cdot \mathrm{kg}^{-1}$ & 29 \\
\hline Ash content & $\%$ & 0.005 & Ash content & $\%$ & 0.0023 \\
\hline $\begin{array}{c}\text { Lubricity, } \\
\text { corrected wear } \\
\text { scar diameter (wsd } \\
1.4) \text { at } 60^{\circ} \mathrm{C}\end{array}$ & $\mu \mathrm{m}$ & & $\begin{array}{c}\text { Lubricity, } \\
\text { corrected wear } \\
\text { scar diameter } \\
\text { (wsd } 1.4 \text { ) at } \\
60^{\circ} \mathrm{C}\end{array}$ & $\mu \mathrm{m}$ & \\
\hline $\begin{array}{c}\text { Filter plugging } \\
\text { point }\end{array}$ & ${ }^{\circ} \mathrm{C}$ & -20 & $\begin{array}{c}\text { Filter plugging } \\
\text { point }\end{array}$ & ${ }^{\circ} \mathrm{C}$ & -40 \\
\hline Acid value & $\mathrm{mg} \mathrm{KOH} \cdot \mathrm{g}^{-1}$ & 0.21 & $\begin{array}{c}\text { Lubricity, } \\
\text { corrected wear } \\
\text { scar diameter } \\
(\text { wsd } 1.4 \text { ) at } \\
60^{\circ} \mathrm{C} \\
\end{array}$ & $\mu \mathrm{m}$ & 432 \\
\hline Iodine value & - & 111.1 & $\begin{array}{c}\text { Distillation } \\
\text { recovered at } \\
250^{\circ} \mathrm{C} \& 350^{\circ} \mathrm{C}\end{array}$ & $\%$ & $\begin{array}{c}1.5 \\
97.5\end{array}$ \\
\hline $\begin{array}{l}\text { Monoglycerides } \\
\text { value }\end{array}$ & $\% \mathrm{wt}$ & 0.70 & $\begin{array}{c}\text { Distillation } \\
\text { recovered at } \\
95 \%(\mathrm{~V} / \mathrm{V})\end{array}$ & ${ }^{\circ} \mathrm{C}$ & 329.2 \\
\hline
\end{tabular}


Table 1 (continued)

\begin{tabular}{|c|c|c|c|c|c|}
\hline \multicolumn{3}{|c|}{ RME } & \multicolumn{3}{|c|}{ Diesel fuel } \\
\hline Characteristic & $\begin{array}{c}\text { Unit of } \\
\text { measurement }\end{array}$ & $\begin{array}{l}\text { Actual } \\
\text { results }\end{array}$ & Characteristics & $\begin{array}{c}\text { Unit of } \\
\text { measurement }\end{array}$ & $\begin{array}{l}\text { Actual } \\
\text { results }\end{array}$ \\
\hline $\begin{array}{c}\text { Acid for } \\
\text { linolenicmethyl } \\
\text { estercontent } \\
\text { values }\end{array}$ & $\% \mathrm{wt}$ & 7.9 & $\begin{array}{l}\text { Fatty acid methyl } \\
\text { ester content }\end{array}$ & $\%$ & $<0.05$ \\
\hline Methanol & $\% \mathrm{wt}$ & 0.01 & Sulphur content & $\mathrm{mg} \cdot \mathrm{kg}^{-1}$ & 7.6 \\
\hline $\begin{array}{l}\text { Glycerides: } \\
\text { monoglycerides } \\
\text { diglycerides } \\
\text { triglycerides } \\
\text { freeglycerides } \\
\text { genericglycerides }\end{array}$ & $\begin{array}{l}\% \mathrm{wt} \\
\% \mathrm{wt} \\
\% \mathrm{wt} \\
\% \mathrm{wt} \\
\% \mathrm{wt} \\
\end{array}$ & $\begin{array}{c}70 \\
19 \\
19 \\
0.005 \\
24 \\
\end{array}$ & - & - & - \\
\hline $\begin{array}{c}\text { Group 1 } \\
\text { formetal(Na+K) } \\
\text { values }\end{array}$ & $\mathrm{mg} \cdot \mathrm{kg}^{-1}$ & 2.3 & - & - & - \\
\hline $\begin{array}{c}\text { Group } 2 \\
\text { formetal }(\mathrm{Ca}+\mathrm{Mg}) \\
\text { values }\end{array}$ & $\mathrm{mg} \cdot \mathrm{kg}^{-1}$ & 4.7 & - & - & - \\
\hline $\begin{array}{c}\text { Phosphorous } \\
\text { values }\end{array}$ & $\mathrm{mg} \cdot \mathrm{kg}^{-1}$ & 1.9 & - & - & - \\
\hline
\end{tabular}

The engine tests were carried outwith full-load characteristics.The test engine was a Valmet 320 DS with its technical specifications being shown in Table 2.

Table 2

Technical specifications for the test engine, Valmet 320 DS

\begin{tabular}{|l|c|}
\hline \multicolumn{1}{|c|}{ Name } & Value \\
\hline Power & $62 \mathrm{~kW}$ at $2400 \mathrm{rev} \cdot \mathrm{min}^{-1}$ \\
\hline Max torque & $285 \mathrm{Nm}$ at $1300 \mathrm{rev} \cdot \mathrm{min}^{-1}$ \\
\hline Soot level on nominal power & $2.8(\mathrm{FSN})$ \\
\hline Soot level on max torque mode $\left(1600 \mathrm{rev} \cdot \mathrm{min}^{-1}\right)$ & $3.5(\mathrm{FSN})$ \\
\hline Soot level measured using methodology MM04-2005 & $3.0(\mathrm{FSN})$ \\
\hline Fuel supply system & Inline injection pump \\
\hline Fuel injection angle & $19 \mathrm{deg} \mathrm{BTDC}$ \\
\hline
\end{tabular}

The combustion process was analysed with the engine at nominal power and at maximum torque. During the tests, measurements were carried out on the engine crankshaft rotational speed, torque, air consumption, fuel consumption, soot level of exhaust fumes, and also the combustion pressure. In addition, the engine oil and cooling liquid temperatures were measured. The testing equipment is shown in Table 3.

Table 3

Test equipment [12]

\begin{tabular}{|ll|}
\hline \multicolumn{2}{|c|}{ Engine test stand- SchenckDynas 3 LI 250 } \\
\hline Maximum torque & $650 \mathrm{Nm}$ \\
\hline Braking power & $250 \mathrm{~kW}$ \\
\hline Max rotational speed & $12,000 \mathrm{rpm}$ \\
\hline Accuracy levels & $0.1 \%$ \\
\hline \multicolumn{2}{|c|}{ Fuel consumption measurement - AVL 7351 } \\
\hline Measurement ranges & $0-125 \mathrm{~kg} / \mathrm{h}$ \\
\hline Measurement uncertainty & $\leq 0.12 \%$ (according to DIN 1319) \\
\hline Response time: & $<125 \mathrm{~ms}$ \\
\hline
\end{tabular}


Table 3 (continued)

\begin{tabular}{|c|c|}
\hline \multicolumn{2}{|c|}{ Engine indication system -AVL 621} \\
\hline Amplifier & AVL 2P2E \\
\hline Pressure sensor GH13P & accuracy $\leq 1.5 \%$ \\
\hline AVL angle encoder $365 \mathrm{C}$ & accuracy $\pm 0.1 \mathrm{deg}$ \\
\hline \multicolumn{2}{|c|}{ Air consumption measurement - Superflow } \\
\hline Superflow & Blade type \\
\hline \multicolumn{2}{|c|}{ Exhaust emission measurement - Bosch BEA 350} \\
\hline CO measuring range $0.000-10.00 \% \mathrm{vol}$ & Resolution $0.001 \%$ \\
\hline $\mathrm{CO}_{2}$ measuring range $0.00-18.00 \%$ vol & Resolution $0.01 \%$ \\
\hline HC measuring range 0-9999 ppm vol & Resolution 1 ppm vol \\
\hline $\mathrm{O}_{2}$ measuring range $0.00-22.00 \%$ vol & Resolution $0.01 \%$ vol \\
\hline$\Lambda$ measuring range $0.500-9.999$ & Resolution 0.001 \\
\hline $\mathrm{NO}$ measuring range $0-5000 \mathrm{ppm}$ vol & Resolution $<=1 \mathrm{ppm} \mathrm{vol}$ \\
\hline Degree of opacity $0-100 \%$ & Resolution $0.1 \%$ \\
\hline Absorption coefficient $0-10 \mathrm{~m}^{-1}$ & Resolution $0.01 \mathrm{~m}^{-1}$ \\
\hline
\end{tabular}

The engine performance parameters have been calculated according to generally-known equations, and these can be found in the reference material for Heywood, 1988 [13]. The combustion process phases can be divided into six categories: 1) air-fuel mixture delay; 2)thermal balance; 3) quick pressure rise phase; 4) main combustion phase; 5) quick pressure decrease phase; and 6) slow pressure decrease phase [14]. The exact TDC is calibrated manually. This means that the engine has been operated with an engine test stand, without the fuel being injected into the cylinder. The compression line maximum point was adjusted on the point of $360 \mathrm{CAD}$ of the angle encoder 365C. Indicom software allowed seeing the compression line and adjusting the TDC precisely. This method enables to make sure that the accuracy of loss angle is at its maximum. The heat release rate (HRR) has been calculated as follows [13]:

$$
\frac{d Q_{n}}{d \varphi}=\frac{\gamma}{\gamma-1} p \frac{d V}{d \varphi}+\frac{1}{\gamma-1} V \frac{d p}{d \varphi}
$$

where $Q_{n}$ - the amount of heat that is released as the fuel burns in the cylinder;

$\gamma$ - the ratio for specific heat $(\gamma=1.4)[15]$;

$p$ - the combustion pressure;

$\varphi-$ the degree of crank angle (CAD);

$V$ - the cylinder volume.

The heat released (HR) has been calculated as follows [13]:

$$
Q_{n}=\frac{d Q_{n}}{d \varphi}+Q_{n . \varphi-1},
$$

where $Q_{n}$ - heat release;

$Q_{n, \phi-1}-$ the energy released in the combustion process for each crank angle (HRR).

The work of one engine cylinder per cycle is expressed by the equation [13]:

$$
W_{n}=\int p d V_{c} .
$$

The total heat released is expressed by the equation [13]:

$$
Q_{n . t e o r}=\int_{\varphi_{b}}^{\varphi_{\text {end }}} \frac{d Q_{n . t e o r}}{d \varphi} d \varphi=q \cdot Q_{f . t e o r},
$$

where $\varphi_{b}$ and $\varphi_{\text {end }}$ - the rotational angles for the crankshaft, signifying the beginning and end of the combustion process;

$q$ - the amount of fuel being injected into the cylinder during one work cycle;

$Q_{\text {fteor }}-$ the calorific value of the fuel $\left(\mathrm{DF}=42.5 \mathrm{MJ} \cdot \mathrm{kg}^{-1}\right.$ and $\left.\mathrm{RME}=36 \mathrm{MJ} \cdot \mathrm{kg}^{-1}[15]\right)$. 
The amount of fuel injected during one work cycle $\left(\mathrm{cm}^{3} \cdot \mathrm{c}^{-1}\right)$ is expressed as follows [12]:

$$
q=\frac{\frac{B_{f}}{i \cdot 60 \cdot 0.001 \cdot p_{\text {fuel }}}}{N_{c}} \cdot 1000
$$

where $B_{f}$ - fuel consumption, $\mathrm{kg} \cdot \mathrm{h}^{-1}$;

$N_{c}$ - the number of work cycles per minute

$\rho_{\text {fuel }}$ - the fuel density level

$i$ - the number of cylinders

The engine tests were carried out using three fuel types: 1) diesel fuel (DF); 2) biodiesel fuel (RME); and 3) a mixture of biodiesel and the fuel additive, Valvoline VPS HD Diesel System Complete (RME_AD). The engine tests using diesel fuel have been provided in order to give a better overview of possible changes in the engine performance parameters, and to understand which changes were caused by the RME fuel and how the fuel additive affects the engine performance parameters. Prior to the measurements, the engine worked for 3 hours on different modes to ensure the impact of the fuel additive.

\section{Results and discussion}

The engine power and torque graphs that were obtained from the engine tests have been provided in Figure 1. Figure 2 shows the general and specific fuel consumption graphs. Figure 1 shows that the engine torque and power decreased by approximately $6 \%$ when the fuel additive was used. When diesel fuel was used, the torque and power indicators remained at the same level as when RME and the mixture of RME and the fuel additive were used. Figure 2 shows that the fuel consumptions for RME and fuel with the fuel additive were similar. In comparison to the figures for diesel fuel, the fuel consumption for RME and RME_AD had increased by about $13 \%$. The increased fuel consumptions were caused by the lower calorific value of the RME fuel and its higher density when compared to diesel fuel.

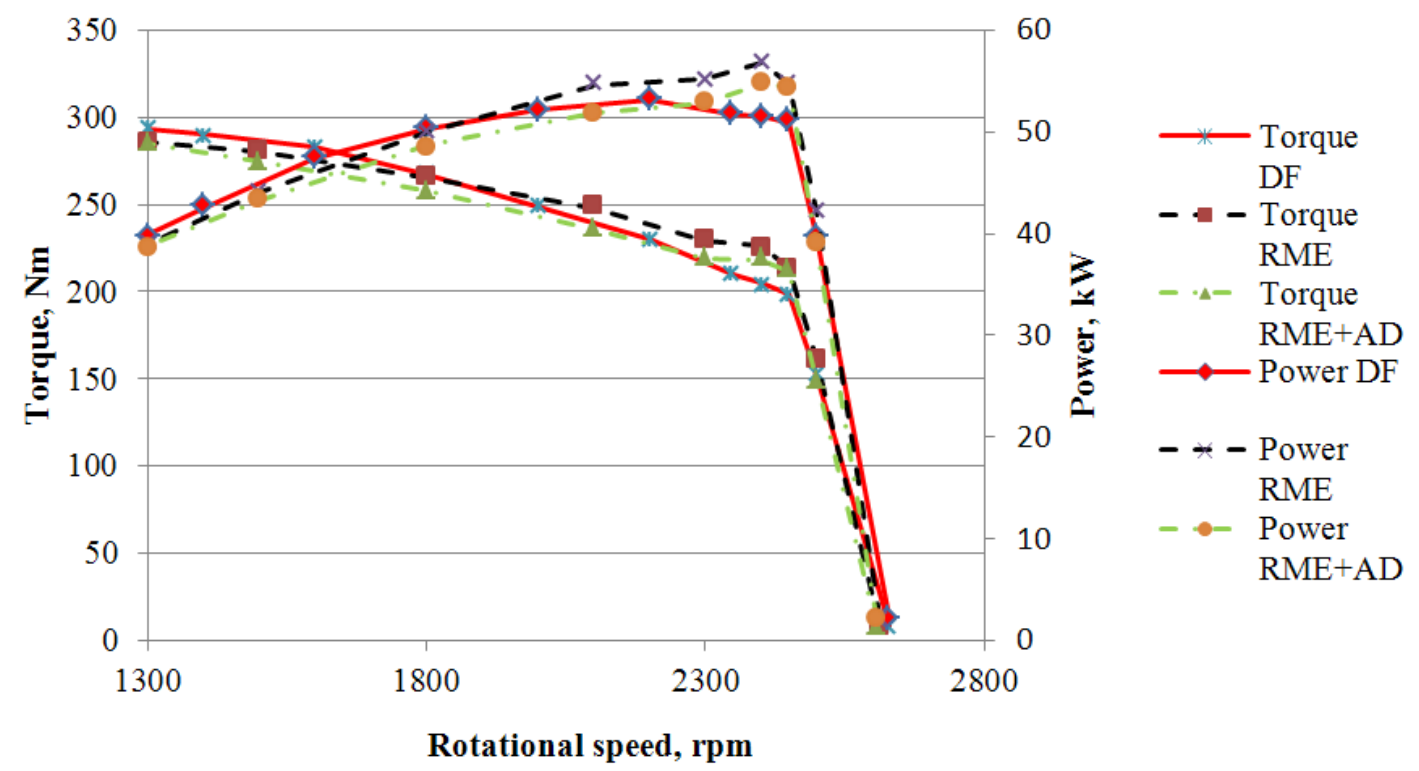

Fig. 1. Engine power and torque [1]

When the engine was set at nominal power, the specific fuel consumption increased by $5 \%$ with the addition of RME_AD when compared to the use of RME. The difference in specific fuel consumption in the engine maximum torque regime $\left(n_{e}=1300 \mathrm{rpm}\right)$ is about $1 \%$. Therefore, the specific fuel consumption increased when the fuel additive was used. When comparing the use of diesel fuel and RME, the specific fuel consumption for RME use increased by $5 \%$ at nominal power and by about $10 \%$ in the engine maximum torque regime. 

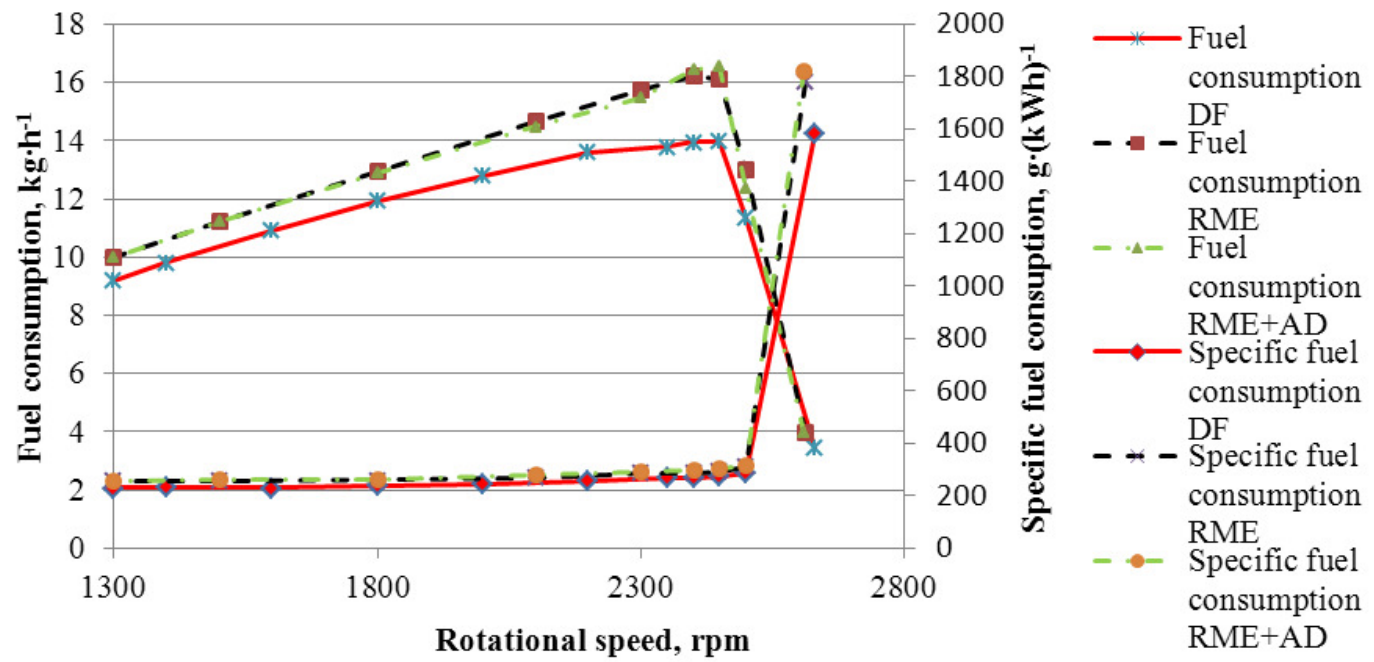

Fig. 2. Engine fuel consumption and specific fuel consumption [1]

It becomes clear from the figures above that the specific fuel consumption is at the highest levels when a fuel mixture is used which contains the fuel additive. On the basis of these figures, it can be claimed that the engine fuel consumption and the specific fuel consumption does not decrease when a fuel with an additive is used. It can be claimed in accordance with the specific fuel consumptions that there are no significant changes in the combustion process.

The soot levels from the engine exhaust fumes have been presented in Figure 3. From the figures shown here, it can be seen that the soot levels in the exhaust fumes do not differ significantly in the use of either RME or RME_AD. The differences amount approximately to 0.01 units. Therefore, the fuel additive does not have a significant impact on reducing the soot levels. When comparing the soot levels from using RME and from using diesel fuel, the soot levels for diesel fuel are $45 \%$ higher than they are for RME. The reduced soot levels registered from using biofuels as engine fuel are a common tendency, one that is caused by the physico-chemical properties of RME [16; 17].

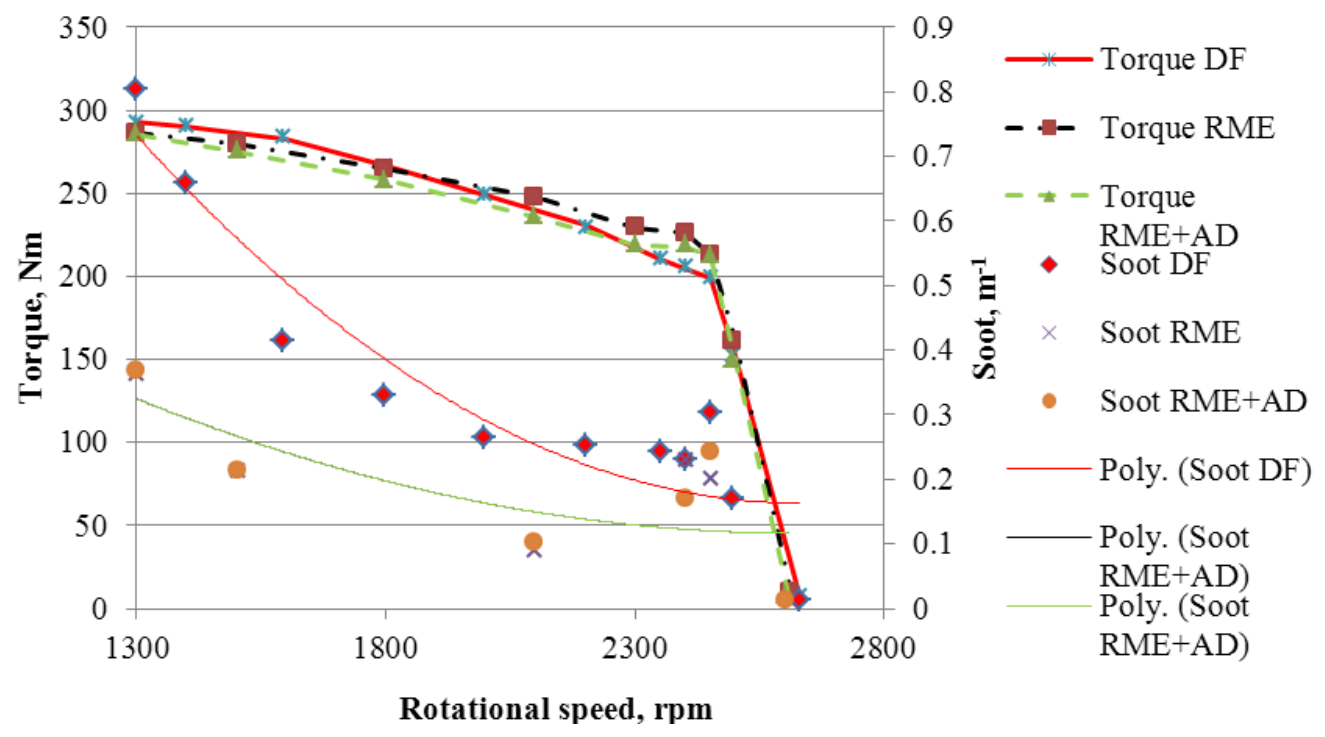

Fig. 3. Engine torque and soot level

The data presented above do not show that the use of the fuel additive, Valvoline VPS HD Diesel System Complete, would have an impact on the engine performance parameters and soot levels. The effect of the fuel additive on the engine combustion process has been shown in Figures 4 and 5.

Figure 4 shows that, with the engine at nominal power, the combustion pressures do not differ significantly at different crankshaft angle positions. Therefore, there is no basis to assume that the fuel additive would affect the combustion process when at nominal power. In the case of diesel fuel, the cylinder pressure in combustion phase V drops faster than it does when RME and RME_AD are used. 
This is caused by the higher proportion of RME and RME_AD fuel in the cylinder, which results in a higher level of exhaust fumes during combustion. It becomes clear from the comparison of HRR graphs that the heat release rate starts one degree earlier than in the case of diesel fuel being used.

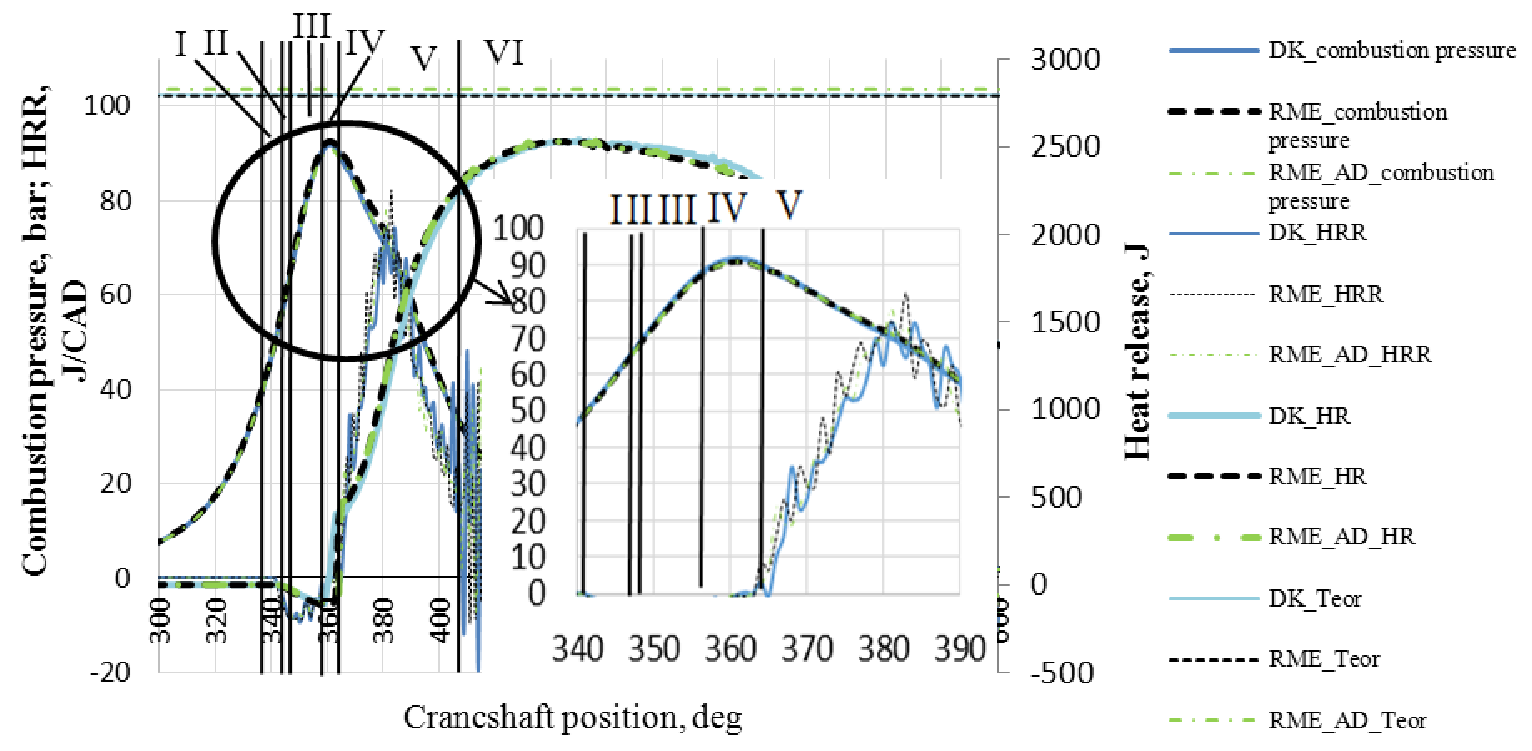

Fig. 4. Combustion process on engine crankshaft rotational speed $n_{e}=2400 \mathrm{rpm}$ (combustion phases I-VI)

The comparison of HRR graphs for RME and RME_AD displays no significant differences. The heat release graph serves to illustrate that a similar amount of energy is released in the cylinder during combustion at various crankshaft rotational speeds. The heat release value for diesel fuel at $460 \mathrm{CAD}$ is higher than it is when using RME and RME_AD; however, the difference is a small one and it levels off at 550 CAD. This is caused by the diesel fuel higher combustion efficiency, which has been reduced in the case of RME and RME_AD due to the higher levels of exhaust fumes. The combustion efficiency has been calculated as the ratio of energy forwarded to the cylinder and energy emitted during combustion. The combustion efficiency for diesel fuel is about $91 \%$, for RME it is about $90 \%$, and for RME_AD it is about $87 \%$. This shows that the fuel additive inhibits combustion in the cylinder. The combustion process under the maximum torque regime has been shown in Fig. 5 .

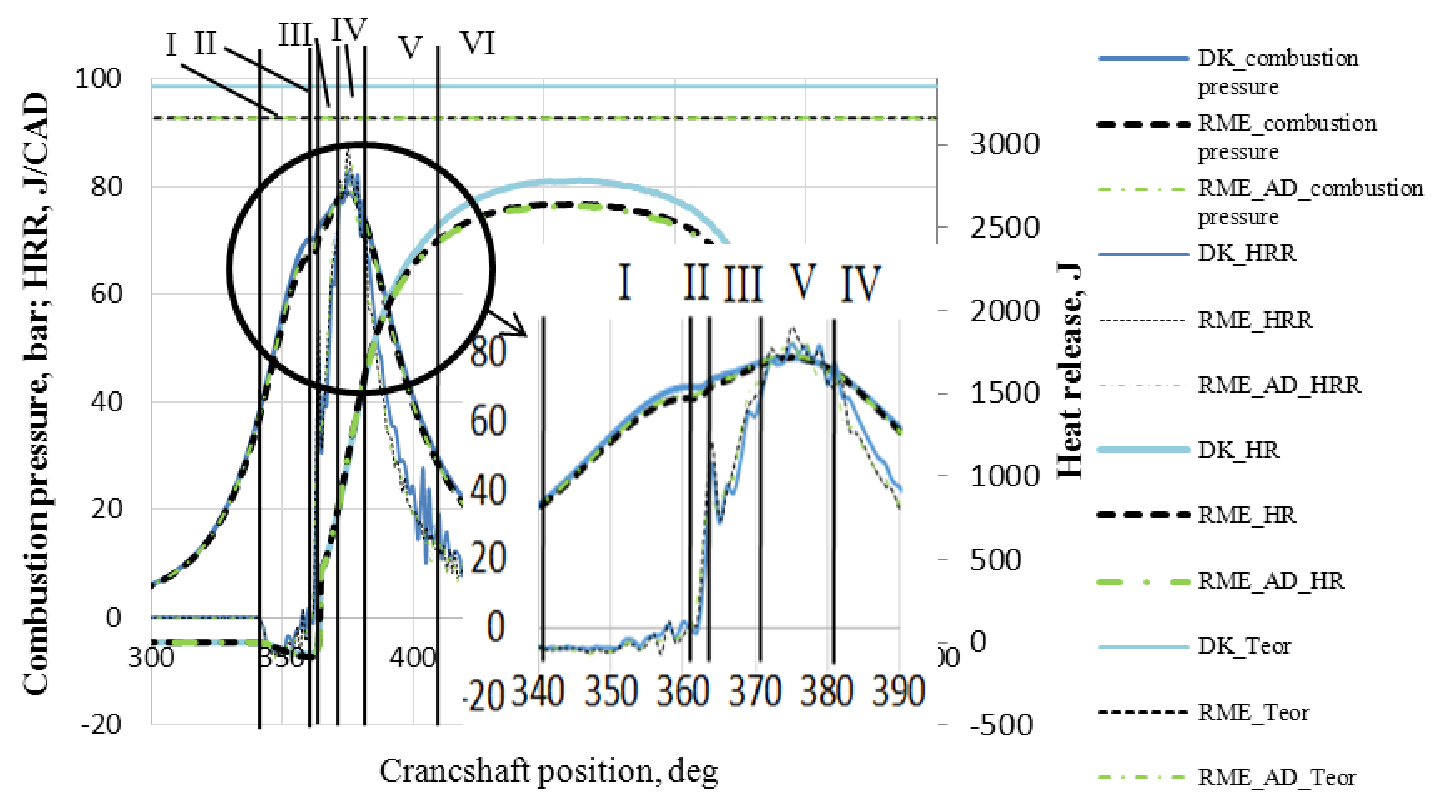

Fig. 5. Combustion process onengine crankshaft rotational speed $n_{e}=1300 \mathrm{rpm}($ combustion phases I - VI) 
It becomes evident from the figures that when RME and RME_AD are used, the combustion pressures during the engine maximum torque regime of $n_{e}=1300 \mathrm{rpm}$ are no different from one another. Similarly, there are no significant differences in the HRR and HR figures, which proves that the fuel additive has no appreciable impact on the combustion process. The combustion efficiency is about $80.5 \%$ when RME is used and $80 \%$ when RME_AD is used. Combustion efficiency is higher when RME is used. The comparison between the combustion process for RME and diesel fuel shows that, when diesel fuel is used, the cylinder pressure is higher in the air-fuel mixture delay phase (I), and the thermal balance phase (II) is about one CAD shorter. This is most probably caused by the somewhat higher cetane number for diesel fuel. The graph shows that, in the case of diesel fuel, the HR is at its highest above 400 CAD. The HRR graphs are similar for all test fuels. The combustion efficiency for diesel fuel is about $79 \%$. The decreased combustion efficiency can be used to explain the increased soot levels for diesel fuel, which is presented in Figure 3. Figure 6 presents the work carried out in the cylinder at nominal power levels and during the maximum torque regime.

a)

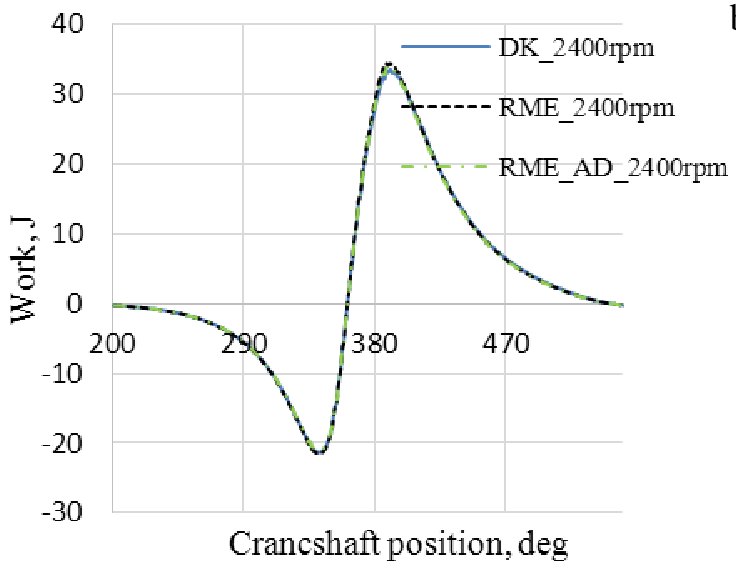

b)

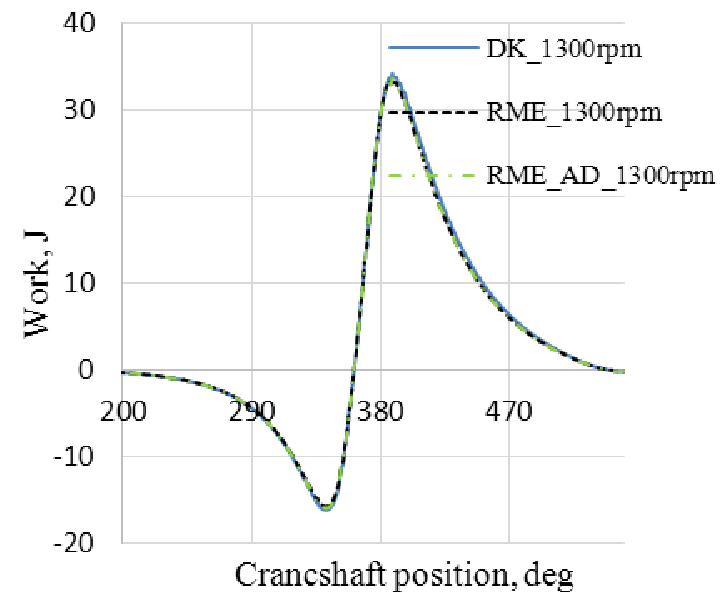

Fig. 6. Cylinder work during engine crankshaft rotational speeds: $\mathrm{a}-n_{e}=2400 \mathrm{rpm}$ and $\mathrm{b}-n_{e}=1300 \mathrm{rpm}$

The figures show that the work, which has been carried out at various crankshaft positions, remains within the same level of magnitude for all fuels and is in conformity with the differences for specific fuel consumption figures shown in Fig. 2 This means that engine work is related to the input energy in the cylinder.

\section{Conclusions}

The following summarising claims can be made about the use of the fuel additive, Valvoline VPS HD Diesel System Complete, in RME fuel:

1. In the current research, no impact of the fuel additive on the engine combustion process was found.

2. When diesel fuel is used, soot levels in exhaust fumes increase in comparison to RME and RME with the fuel additive, which is a factor that is related to decreased combustion efficiency as the engine load increases.

3. The values for the heat release rates do not differ significantly between diesel fuel, RME, and RME with the fuel additive.

4. There are no significant differences in the heat release rate for RME and RME with the fuel additive.

5. The amount of work that has been carried out on the engine cylinder is equal for diesel fuel, RME, and RME with the fuel additive.

In general, combustion depends on the physico-chemical properties of the fuel in the engine cylinder. Comparing the combustion efficiency, it can be concluded that using the fuel additive tends to inhibit rather than improve the engine combustion process. 


\section{References}

1. Baranauskas R., Ilves R., Küüt A., Olt J. Influence of the biodiesel fuels with multifunctional additives on the diesel engine efficiency. Proceedings of the 7th International Scientific Conference Rural Development, 2015.

2. Kreicbergs J., Grislis A.,. Zalcmanis G, Rudzitis J. Effect of modified diesel fuel on enginefuelefficency. Engineering for Rural Development. Jelgava, 2014, pp. 283-287.

3. Küüt A., Ilves R., Vlasov A., Soots K., Olt J. Impact of bioethanol fuel on the output parameters of a two-stroke reciprocating engine. Engineering for Rural Development, Jelgava, 29.30.05.2014.LatviaUniversity of Agriculture, 2014, pp. 288-295.

4. Mägi M. Effect of Gasoline Fuel Additives on Combustion and Engine Performance. Doctoral thesis, University College London, 2015.

5. Patil A.R., Taji S.G. Effect of Oxygenated Fuel Additive on Diesel Engine Performance and Emission: A Review. IOSR Journal of Mechanical and Civil Engineering (IOSR-JMCE) ISSN(e): 2278-1684, ISSN(p) : 2320-334X, 2013, pp. 30-35.

6. Küüt A., Ilves R., Hönig V., Vlasov A., Olt J. The impact of bioethanol on two-stroke engine work details and exhaust emission. Agronomy Research, 13 (5), 2015, pp. 1241-1252.

7. Soveran D.W., Sulatisky M., Ha K., Robinson W., Stumborg M. The effect on diesel engine emissions with high cetane addltives from biomass oils. [online][12.12.2016] Available at: https://web.anl.gov/PCS/acsfuel/preprint\%20archive/Files/37_1_SAN\%20FRANCISCO_0492_0074.pdf

8. Zerda T.W., Yuan X., Moore S.M. Effects of fuel additives on the microstructure of combustion engine deposits. Carbon 39, Permagon, 2001., pp. 1589-1597.

9. Wilkins A.J.J., Hanningon N.A. The Effect of Fuel and Oil Additives on Automobile Catalyst Performance. The suitability of platinum metals confirmed. Platinum Metals Rev., 1990, 34, (1), pp. 16-24.

10. Lapuerta M., Herreros J.M., Lyons L., Garcia-Contreras R., Briceno Y. Effect of the alcohol type used in the production of waste cooking oil biodiesel on diesel performance and emissions. Fuel, Vol. 87, Iss.15-16, 2008, pp. 3161-3169.

11. Valipour A.A Review on Effect of FuelAdditives on Combustion, Performance and EmissionCharacteristics of Diesel and Biodiesel Fuelled Engine. International Journal of Application or Innovation in Engineering \& Management (IJAIEM), 2014, pp. 266-273.

12. Ilves R. Fuel supply system of piston engine working on liquid biofuels. Dissertation thesis, Estonian University of Life Sciences. 2014, Ecoprint, Estonia.

13. Heywood J.B. 1988. Internal Combustion Engine Fundamentals. McGraw-Hill. 930 S.

14. Olt J., Mikita V., Roots J., Jasinskas J. Cylinder Pressure Characteristics of Turbocharged and Naturally Aspirated Diesel Engines. Annals of DAAAM for 2014 \&Proceedings of the 25st International DAAAM Symposium. Procedia Engineering 100, 2015, pp. 350-359.

15. Merker G.P., Schwarz C., Teichmann R. 2012. Grundlagen Verbrennungsmotoren. Funktsionsweise, Simulation, Messtechnik, Aufgabe 6. Springer Fachmedien Wiesbaden gmgh.795 S. (in German)

16. Pexa M. Čedík J. Pražan R. Smoke and NOX emissions of combustion engine using biofuels. Agronomy Research, 14(2), 2016, pp. 547-555.

17. Wang Z., Li L., Wang J., Reitz R.D. Effect of biodiesel saturation on soot formation in diesel engines. Fuel, Volume 175, 2016, pp. 240-248. 